\title{
Treatment of a textile dye in the anaerobic baffled reactor
}

\author{
Joanne Bell and Chris A Buckley* \\ Pollution Research Group, School of Chemical Engineering, University of Natal, Durban, 4041, South Africa
}

\begin{abstract}
Synthetic organic colourants, the majority of which are recalcitrant in nature, are used in many different manufacturing processes. The dyes are released into the environment in industrial effluents and are highly visible even at low concentrations $(<1 \mathrm{mg} / \mathrm{l})$. Decolorisation of the dye CI Reactive Red 141 was investigated in a laboratory-scale anaerobic baffled reactor (ABR). The results of the physical decolorisation tests suggested significant decolorisation due to adsorption to the biomass; however, it is possible that the dye chromophores were reduced due to the low redox potential environment within the test bottles. No dye breakthrough, due to adsorption saturation, was observed during operation of the reactor. COD reduction was consistently $>90 \%$. Colour reduction averaged $86 \%$. The biomass showed acclimation to the dye, with increased methanogenic activity with each increase in dye concentration. The reactor operation was stable, even with increases in the dye concentration. This investigation has shown that successful treatment of a highly coloured wastewater is possible in the ABR.
\end{abstract}

Keywords: Anaerobic baffled reactor, textile dyes, CI Red 141

\section{Introduction}

The successful application of anaerobic technology to the treatment of industrial wastewaters depends on the development of high-rate bioreactors, which achieve a high reaction rate per unit reactor volume by retaining the biomass in the reactor for long periods of time (solids retention time - SRT), independent of the hydraulic retention time (HRT). While there have been many highrate designs developed, the ABR has many advantages compared to these, such as:

- better resilience to hydraulic and organic shock loads,

- longer biomass retention times, lower sludge yields, and

- the ability to partially separate the various phases of anaerobic catabolism (Barber and Stuckey, 1999).

The ABR is a high-rate reactor that contains between 3 and 8 compartments in which the liquid flow is alternately upwards and downwards between compartment partitions (for a review see Barber and Stuckey, 1999). During upflow, the waste flows through an anaerobic sludge blanket and is thus in contact with the active biomass but, because of the design, most of the biomass is retained within the reactor.

Dye wastewaters enter the environment from dye manufacturers and dye consumers, e.g. textile, leather and food industries (Cooper, 1995), usually in the form of a dispersion or a true solution (Seshadri et al., 1994), and often in the presence of other organic compounds. Dyes are normally present in dyehouse effluent at concentrations of 10 to $50 \mathrm{mg} / \mathrm{l}$ (Laing, 1991). CIReactive Red 141, or Evercion Red HE7B, is an azo reactive dye (Fig. 1) with a molecular mass of $1634 \mathrm{Da}$. The dye is representative of a dye class known to be problematic with treatment in a conventional wastewater treatment system; reactive dyes are hydrophilic, there-

* To whom all correspondence should be addressed.

盄+27 31260 3375; fax: +27 31260 1118; e-mail: buckley@nu.ac.za Received 16 October 2002; accepted in revised form 3 March 2003. fore, they have little affinity to adsorb to biomass and generally pass through activated sludge systems (Bell, 1998). The red hue is known to give rise to aesthetic problems at relatively low concentrations. Previous investigations have determined the reaction kinetics of CI Reactive Red 141 (Carliell, 1993; Carliell et al., 1994; Carliell et al., 1995; Carliell et al., 1996; Bell, 1998).

It was hypothesised that anaerobic digestion, in the ABR, could reduce the COD and colour of a CI Reactive Red 141 waste stream at a low $(20 \mathrm{~h})$ hydraulic retention time (HRT). The objectives of this investigation were to determine whether adsorption to the anaerobic biomass played a significant role in the decolorisation of the waste stream, to assess the feasibility of the ABR for treatment of a CI Reactive Red 141 waste stream; including reduction of COD and decolorisation, evaluate any impact on reactor performance with increasing dye concentrations, and to determine whether the anaerobic biomass became acclimated to the dye, thereby improving degradation and decolorisation, with time.

\section{Materials and methods}

A batch control run (data not shown) investigated the difference in degradation potential of both un-hydrolysed and hydrolysed dyes. Four azo dyes were hydrolysed, to imitate their form in a wastewater stream, by raising the $\mathrm{pH}$ to 11 with $0.2 \mathrm{M} \mathrm{NaOH}$ and heating at $80^{\circ} \mathrm{C}$ for $2 \mathrm{~h}$. There was a negligible difference in the results, thus un-hydrolysed dyes were used for the remainder of the study.

Physical decolorisation: Two tests were conducted to determine the extent of adsorption of CI Reactive Red 141 to the digester sludge since this could contribute to the decolorisation potential in the ABR. The test conditions are outlined in Table 1 .

In Test 1 , mixed anaerobic digester sludge collected from the Umbilo Sewage Works (Pinetown, South Africa) was inactivated by autoclaving at $121^{\circ} \mathrm{C}$ for $80 \mathrm{~min}$. Once the sludge had cooled, aliquots were transferred into a series of serum bottles. The CI Reactive Red 141 dye stock solution was diluted to the required concentration ( $2 \mathrm{~g} / \mathrm{l})$. In Test 2 , sodium azide, which is an inhibitor 


\begin{tabular}{|c|l|c|c|}
\hline \multicolumn{4}{|l|}{ TABLE 1} \\
Test conditions to assess the extent of physical decolorisation of CI Reactive Red 141 \\
\hline Test & Sludge & Dye & Chemical addition \\
\hline Test 1 & $\begin{array}{l}\text { Non-acclimated } \\
\text { Autoclaved }\left(80 \text { min at } 121^{\circ} \mathrm{C}\right)\end{array}$ & $2 \mathrm{~g} / \mathrm{l}$ CI Red 141 & None \\
Test 2 & $\begin{array}{l}\text { Non-acclimated } \\
\text { Un-autoclaved }\end{array}$ & $0.05 \mathrm{~g} / \mathrm{l}$ sodium azide \\
\hline
\end{tabular}

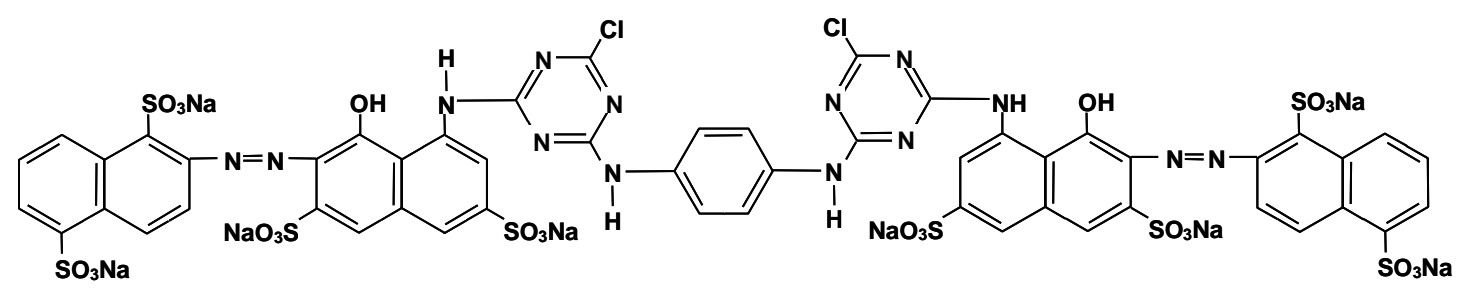

Figure 1

Chemical structure of Cl Reactive Red 141

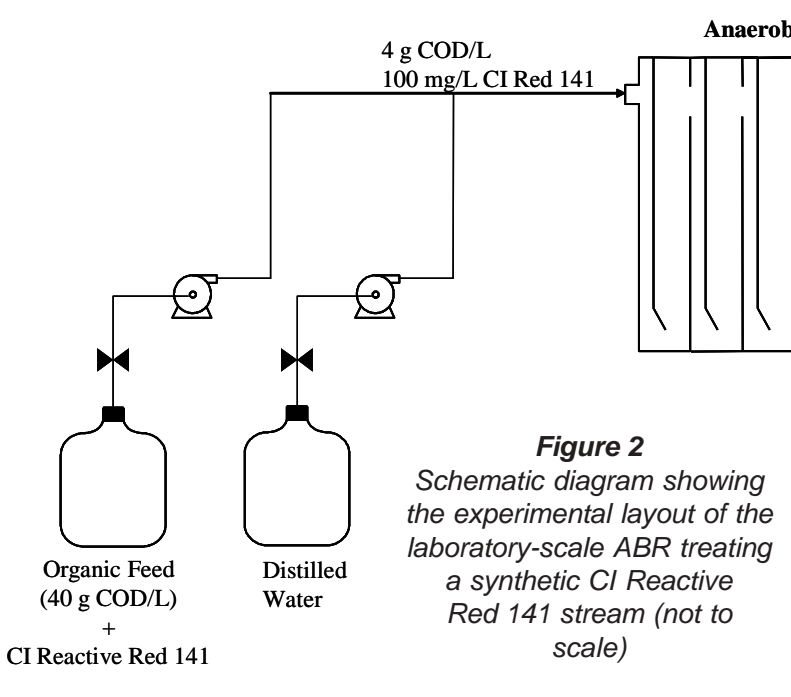

of metabolic activity, was added to give a final concentration of $0.05 \mathrm{~g} / \mathrm{l}$ in the serum bottle. For each test, a control was set up, containing the same amount of sludge, with no dye. The function of the controls was to evaluate the background absorbance of the sludge. The bottles were sealed and incubated in a constant temperature room, at $35^{\circ} \mathrm{C}$. Samples were periodically taken from the bottles, over $7 \mathrm{~d}$. Immediately after their collection, the samples were centrifuged $(10000 \mathrm{r} / \mathrm{min})$ for $5 \mathrm{~min}$ and the supernatant liquor filtered through glass-fibre filters $(0.45 \mu \mathrm{m})$. The samples were diluted 1 in 5 with distilled water and then analysed using a spectrophotometer at $545 \mathrm{~nm}$ (maximum absorbance) to determine the dye concentration. The results of each test are presented and discussed below.

Experimental design: An 8-compartment laboratory-scale ABR was set up in a constant temperature room at $35^{\circ} \mathrm{C}$. The reactor was seeded with $7.68 \mathrm{I}(0.96 \mathrm{l} /$ compartment $)$ of screened digester sludge taken from Umbilo Sewage Works (total solids $=28 \mathrm{~g} / \mathrm{l}$; volatile solids $=20 \mathrm{~g} / \mathrm{l})$. The sludge was left to settle for one week before feeding began. The feed connections for CI Reactive Red 141 degradation are illustrated in Fig. 2. The synthetic feed containing (per litre): sucrose (standard white sugar), $0.67 \mathrm{~g}$; peptone, $0.2 \mathrm{~g}$; meat extract, $0.07 \mathrm{~g} ; \mathrm{K}_{2} \mathrm{HPO}_{4}, 0.02 \mathrm{~g} ; \mathrm{NaHCO}_{3}, 0.81 \mathrm{~g}$; and also the trace minerals $\mathrm{CoCl}_{2} \cdot 6 \mathrm{H}_{2} \mathrm{O}, \mathrm{FeCl}_{2} \cdot 4 \mathrm{H}_{2} \mathrm{O}, \mathrm{MnCl}_{2} \cdot 4 \mathrm{H}_{2} \mathrm{O}$, $\mathrm{Na}_{2} \mathrm{MoO}_{4} \cdot 2 \mathrm{H}_{2} \mathrm{O}$ and $\mathrm{NiCl}_{2} \cdot 6 \mathrm{H}_{2} \mathrm{O}$ was fed to the reactor during startup (Bell, 2002). Once the reactor had reached steady state, at a $20 \mathrm{~h}$ HRT, the CI Reactive Red 141 dye was added to the feed solution. The dye powder $(2 \mathrm{~g})$ was diluted in $2 \mathrm{I}$ of the sterilised feed solution (concentration of $40 \mathrm{~g}$ COD/l). The feed was diluted 10x with distilled water, such that the feed to the reactor contained a dye concentration of $100 \mathrm{mg} / \mathrm{l}$. The COD concentration to the reactor was maintained at $4 \mathrm{~g} \mathrm{COD/l}$, which represented the COD of waste streams produced in the dyeing process; the COD of the dye was negligible. To achieve acclimation, the concentration of CI Reactive Red 141 was increased stepwise from $100 \mathrm{mg} / \mathrm{l}(0.12 \mathrm{~g} / \mathrm{l} . \mathrm{d})$, to 250 $\mathrm{mg} / \mathrm{l}(0.3 \mathrm{~g} / \mathrm{l} . \mathrm{d})$ on Day 96, to $500 \mathrm{mg} / \mathrm{l}(0.6 \mathrm{~g} / \mathrm{l} . \mathrm{d})$ on Day 127 . Throughout the experimental period, the reactor was supplied with a constant COD loading of $4.8 \mathrm{~g}$ COD/l.d of the synthetic feed cosubstrate.

Analytical methods: The reactor was sampled and analysed as described previously (Bell et al., 2000). The composition of biogas samples $(0.2 \mathrm{ml})$ was analysed by GC (GowMac 350 GC-TCD) with a Poropak N column (1 $500 \mathrm{~mm}$ x $6.35 \mathrm{~mm})$. To determine colour, samples were centrifuged $(10000 \mathrm{r} / \mathrm{min})$ for $5 \mathrm{~min}$, the supernatant liquor was filtered through glass-fibre $(0.45 \mu \mathrm{m})$ filters, whilst being kept anaerobic by bubbling oxygen-free nitrogen gas through the solution. The absorbance was measured immediately on the UV-VIS Spectrophotometer (Pharmacia Biotech Ultrospec $2000 \mathrm{UV} / \mathrm{VIS}$ ), in quartz microcuvettes ( $\mathrm{vol}=1.5 \mathrm{ml}$; path length $=10 \mathrm{~mm}$ ) at $545 \mathrm{~nm}$. 


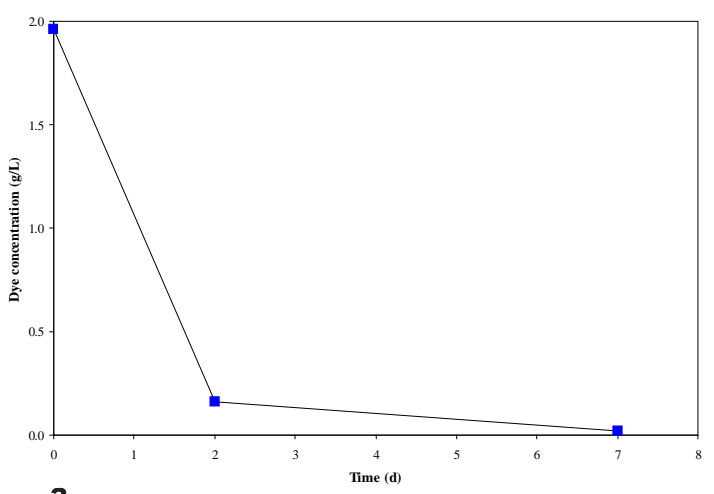

a

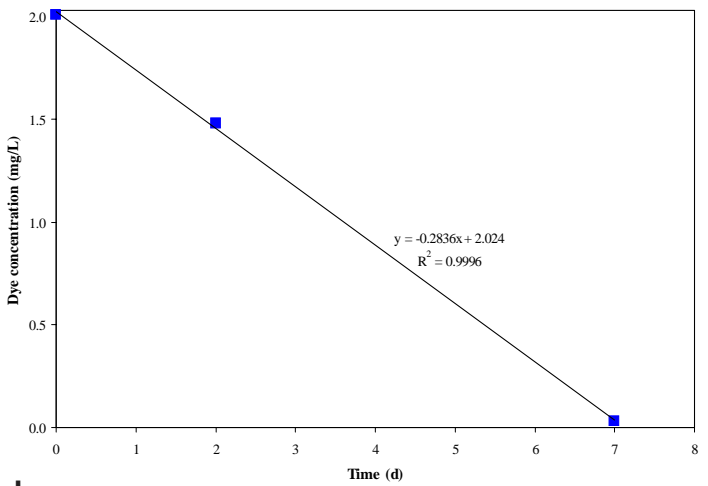

b

Figure 3

Results showing the Cl Reactive Red 141 concentration measured over time for (a) the adsorption Test 1, with autoclaved biomass and (b) adsorption Test (2), with sodium azideinactivated biomass

\section{Results and discussion}

The results of the physical decolorisation Test 1 (Fig. 3(a)) showed almost complete decolorisation. The decolorisation in these bottles was due to adsorption to the biomass but the results may not be completely representative since the autoclaving may have increased the surface area available for adsorption by rupturing the cells. It is also unknown whether all of the biomass was inactivated by autoclaving, therefore, some of the decolorisation may have been due to degradation or breakdown of the dye although this is unlikely since no biogas was produced in any of the assay bottles and enzymes would be denatured at $121^{\circ} \mathrm{C}$. The decolorisation could have occurred due to the reducing conditions of the liquid associated with the biomass or the change in the redox potential due to the autoclaving of the biomass.

The results of Test 2 (Fig. 3 (b)) exhibited linear decolorisation with time. There was some biogas production in these assay bottles which suggests that the biomass was not completely inactivated by the sodium azide (the concentration may have been too low) and that some of the decolorisation may have been due to metabolic degradation or associated reduced conditions. The results of these tests suggest significant decolorisation due to adsorption to the biomass; however, it is also possible that the dyes were reduced due to the anaerobic, or reducing environment within the serum bottles (sodium azide is a reducing agent). Further tests could incorporate sodium azide alone to determine the concentration at which it is completely inhibitory, or investigation of another metabolic inhibitor. The adsorption capacity of normal, untreated biomass should
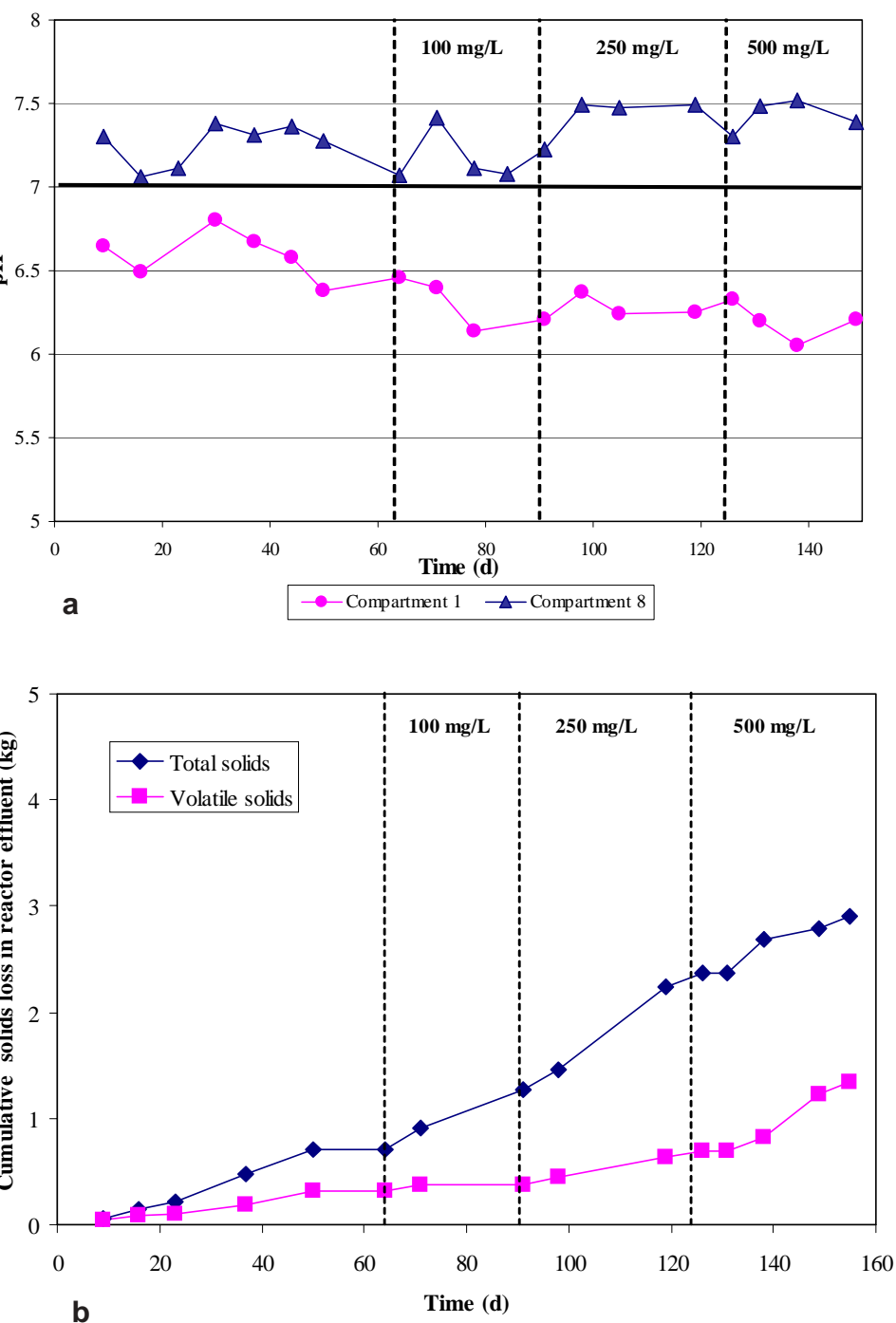

Figure 4

Results showing (a) the $\mathrm{pH}$ profiles through the reactor and (b) the cumulative solids lost from the reactor, during the experimental period

be determined. There is a finite capacity for the biomass to adsorb dye and this will be limited by the generation of new cells.

Figure 4 (a) shows the $\mathrm{pH}$ measured in Compartments 1 and 8 of the ABR. The dotted lines indicate the changes in dye concentration in the feed. These data show that changes in the dye concentration had a slight effect on the reactor $\mathrm{pH}$ and also illustrate the horizontal separation of acidogenesis and methanogenesis through the ABR (Bell, 2002). The $\mathrm{pH}$ in Compartment 1 dropped with the addition of the dye to the feed stream and with each subsequent increase in dye concentration. This could be attributed to the production of volatile fatty acids due to the degradation of sugars in the synthetic feed (Bell, 2002). The $\mathrm{pH}$ in Compartment 8 was not affected which illustrates the ability of the compartmentalised reactor to protect the more sensitive methanogenic species, in the later compartments, from inhibitory components or concentrations in the feed stream.

Figure 4 (b) is a plot of the cumulative solids washed out of the reactor. The measure of volatile solids was taken as an indication of the biomass concentration. These results show that there was biomass washout with each change in dye concentration and that the total amount of solids lost was relatively high (3.37 kg of which 

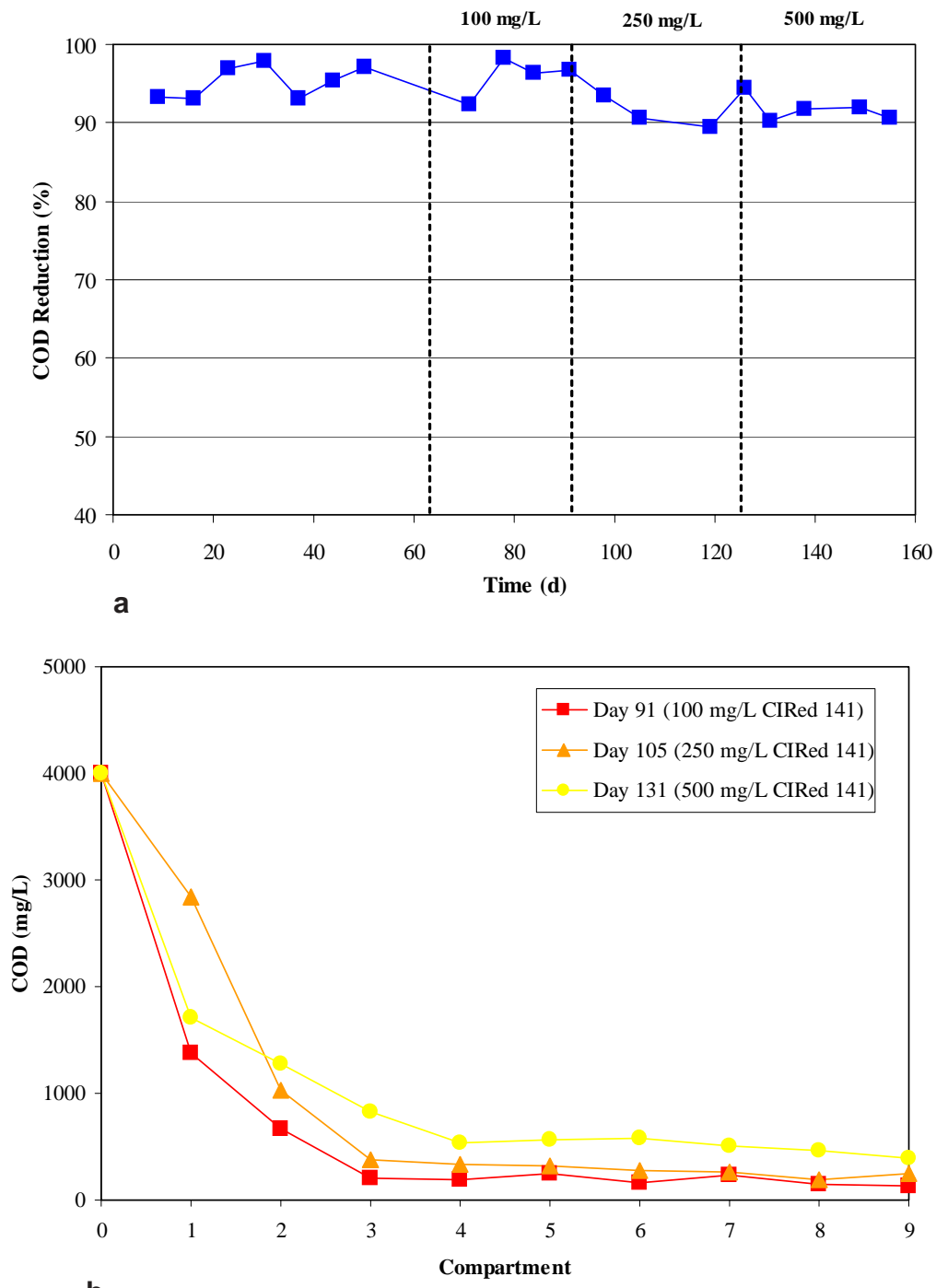

b

Figure 5

$C O D$ measurements in (a) the reactor effluent and (b) within each compartment, during the experimental period

$1.47 \mathrm{~kg}$ were volatile solids).

Figure 5 (a) shows the soluble COD removed by the reactor over time. The COD removal during start-up, or before the addition of the dye to the feed stream, averaged $95 \%$, or an effluent COD of $189 \mathrm{mg} / \mathrm{l}$. A COD removal efficiency of $>80 \%$ is considered acceptable to conclude the start-up period (Willetts, 1999). CI Reactive Red 141 was added to the feed stream at a concentration of $100 \mathrm{mg} / \mathrm{l}$, on Day 65. This resulted in a slight decrease in the COD reduction with an effluent COD of $303 \mathrm{mg} / \mathrm{l}$. The COD reduction stabilised within $3 \mathrm{HRT}$ to give an effluent COD concentration of $163 \mathrm{mg} / \mathrm{l}$. The average COD reduction for the complex feed containing $250 \mathrm{mg} / \mathrm{l}$ dye concentration was $92 \%$ and $91 \%$ for the $500 \mathrm{mg} / \mathrm{l}$ concentration. Thus, there was a slight decrease in the COD removal efficiency with each increase in the dye concentration.

Figure 5 (b) shows the COD profiles through the reactor, at different time periods during the experiment. On the plot, Compartment 0 represents the reactor feed and Compartment 9 represents the reactor effluent. The profiles show that the majority of the COD was reduced in the first three compartments of the reactor. The
COD profiles indicate that the COD reduction decreased with each increase in dye concentration. This could be attributed to reduced metabolic activity of the methanogens (degrading the intermediates from the sucrose in the feed) since they were shown to be inhibited by CI Reactive Red 141 and its degradation products (Bell, 2002). The profiles also show very little COD reduction in the last three compartments of the reactor; this was substantiated by the biogas results and the population characterisation experiments (Bell, 2002), which showed low metabolic activity in these compartments.

The concentration of CI Reactive Red 141 in the influent was increased periodically after at least 20 hydraulic retention times (HRT of $20 \mathrm{~h}$ ) and when more than $75 \%$ removal of the dye and the cosubstrate (sucrose in the synthetic feed) COD had been achieved. Figure 6 (a) shows the colour reduction with time. These results show efficient decolorisation of the CIReactive Red 141 waste stream. The colour reduction averaged $87 \%$ with a 100 $\mathrm{mg} / \mathrm{l}$ dye concentration in the feed and $85 \%$ for the $250 \mathrm{mg} / \mathrm{l}$ concentration. The colour removal dropped to $65 \%$ when the dye concentration was increased to $500 \mathrm{mg} / \mathrm{l}$ (Day 127). This was the lowest colour removal achieved throughout the duration of the test, and had increased to $80 \%$ within one HRT. Thus, colour removal was efficient with an average colour removal of $86 \%$ over the whole test period. The minimum dye concentration achieved in the effluent was $5 \mathrm{mg} / \mathrm{l}$, on Day 91; however, this concentration is still significant since colour is visible at concentrations $<1 \mathrm{mg} / \mathrm{l}$. The effluent would require further treatment before discharge to a water source. If this colour reduction was achieved by pretreatment at the factory, further aerobic reduction of the aromatic amines could be achieved by conventional treatment at a wastewater treatment works.

The colour reduction profiles (Fig. 6 (b)) show that, for all investigated dye concentrations, at least $50 \%$ of the colour was removed in the first two compartments of the reactor. The results of the adsorption assays indicated that adsorption would contribute significantly to the decolorisation of the CI Reactive Red 141 waste stream. If decolorisation was only achieved by adsorption, i.e. there was no reduction of the dye molecules, then the biomass would have reached a saturation point where no more dye molecules could be adsorbed and a break-through of dye would have been observed in the reactor effluent. This was not observed, therefore it was concluded that there was also metabolic reduction of the dye molecules contributing to the decolorisation of the dye waste.

The methane composition is given as a mole fraction of the total biogas (Fig. 7). The profile plot shows that for all of the investigated dye concentrations, the methane composition of the biogas increased in each compartment, from Compartment 1 through to a maximum methane composition in either Compartment 5 or 6 (ca. 70\%). In all cases the methanogenic activity was low in Compartments 7 and 8 which could indicate that the methanogens in these compartments (predominantly the scavenging Methanosaeta spp.) were inhibited by the dye degradation products, or that the organic load to the reactor was such that the metabolic activity in these compartments was low. This correlates with the COD results. 
This investigation has shown that successful treatment of a highly coloured wastewater is possible in the ABR. The results of the physical decolorisation tests suggested significant decolorisation due to adsorption to the biomass; however, it is possible that the dye chromophores were reduced due to the low redox potential environment within the test bottles. Although there was some inhibition of the methanogens with each increase in the dye concentration (up to $0.5 \mathrm{~g} / \mathrm{l}$ ), the COD and colour removal were efficient. The results of this experiment showed very low metabolic activity in the final three compartments of the reactor, therefore, in a pilotor full-scale design, these compartments could be removed. If the dye wastewater was to be treated with a high-strength COD wastewater, the metabolic activity in the last three compartments would be higher and facilitate further COD reduction.

\section{Acknowledgements}

The authors wish to acknowledge the financial support of the South African Water Research Commission, the University of Natal Research Fund and the National Research Foundation.

\section{References}

BARBER W and STUCKEY D (1999) The use of the anaerobic baffled reactor (ABR) for wastewater treatment: A review. Water Res. 33 (7) 1559-1578.

BELL CB (1998) Biological Decolourisation of Textile Effluent in a Nutrient Removal System. M.Sc. Eng Thesis. School of Chem. Eng., Univ. of Natal, Durban.

BELL J, PLUMB JJ, BUCKEY CA and STUCKEY DC (2000) Treatment and decolourisation of dyes in an anaerobic baffled reactor. J. Environ. Eng. 126 10261032.

BELL J (2002) Treatment of Dye wastewaters in the Anaerobic Baffled Reactor and Characterisation of the Associated Microbial Populations. Ph.D. Thesis, School of Chem. Eng., Univ. of Natal, Durban.

CARLIELL CM (1993) Biological Degradation of Azo Dyes in an Anaerobic System. M.Sc. Eng. Thesis. School of Chem. Eng., Univ. of Natal, Durban.

CARLIELL CM, BARCLAY SJ, NAIDOO N, BUCKLEY CA, MULHOLLANDDA and SENIOR E (1994) Anaerobic decolourisation of reactive dyes in conventional sewage treatment processes. Water SA 20 (4) 341-344.

CARLIELL CM, BARCLAY SJ, NAIDOO N, BUCKLEY CA, MULHOLLANDDA and SENIOR E (1995) Microbial decolourisation of a reactive azo dye under anaerobic conditions. Water SA 21 (1) 61-69.
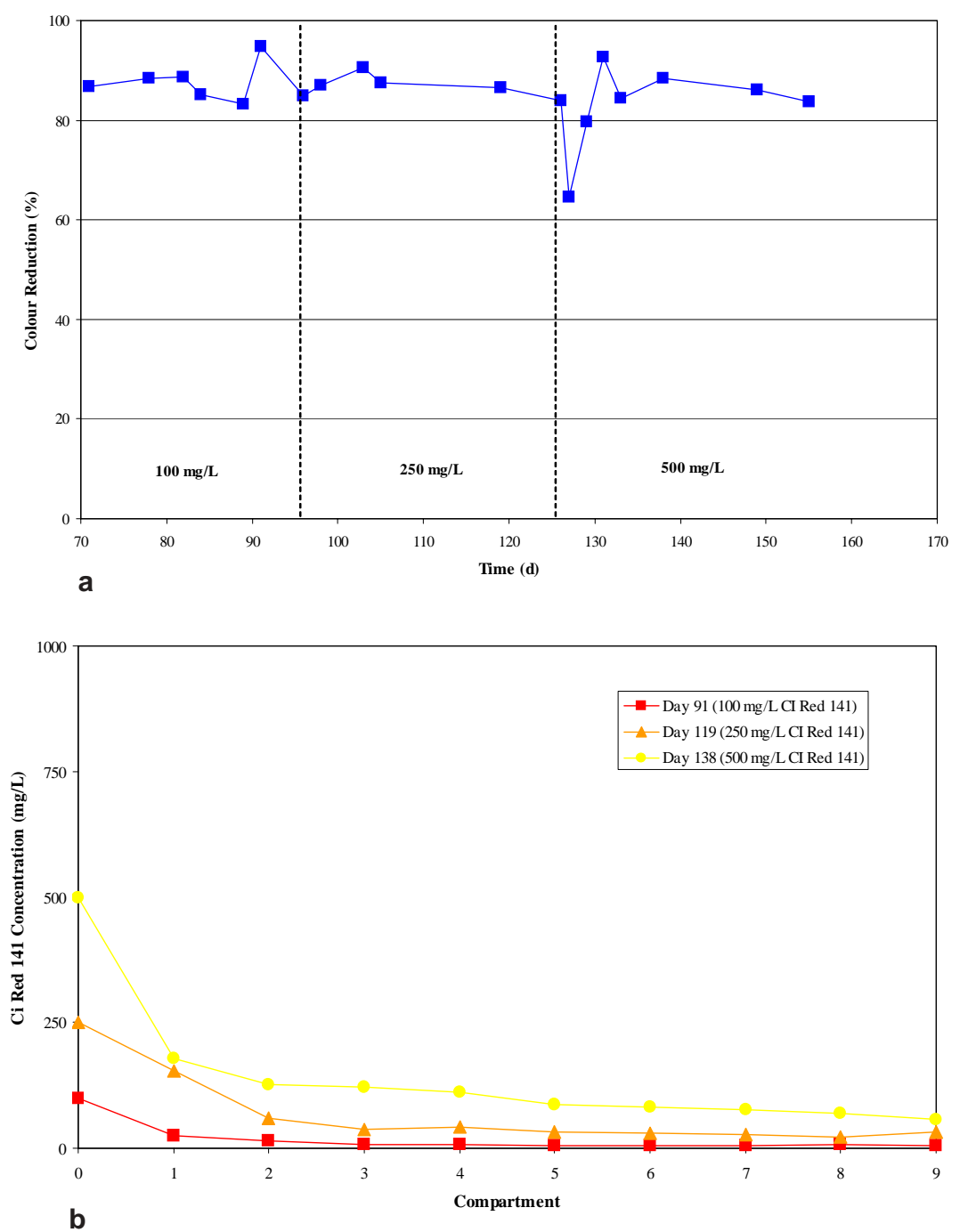

Figure 6

Results showing (a) the colour removal and (b) the colour reduction profiles, during the experimental period

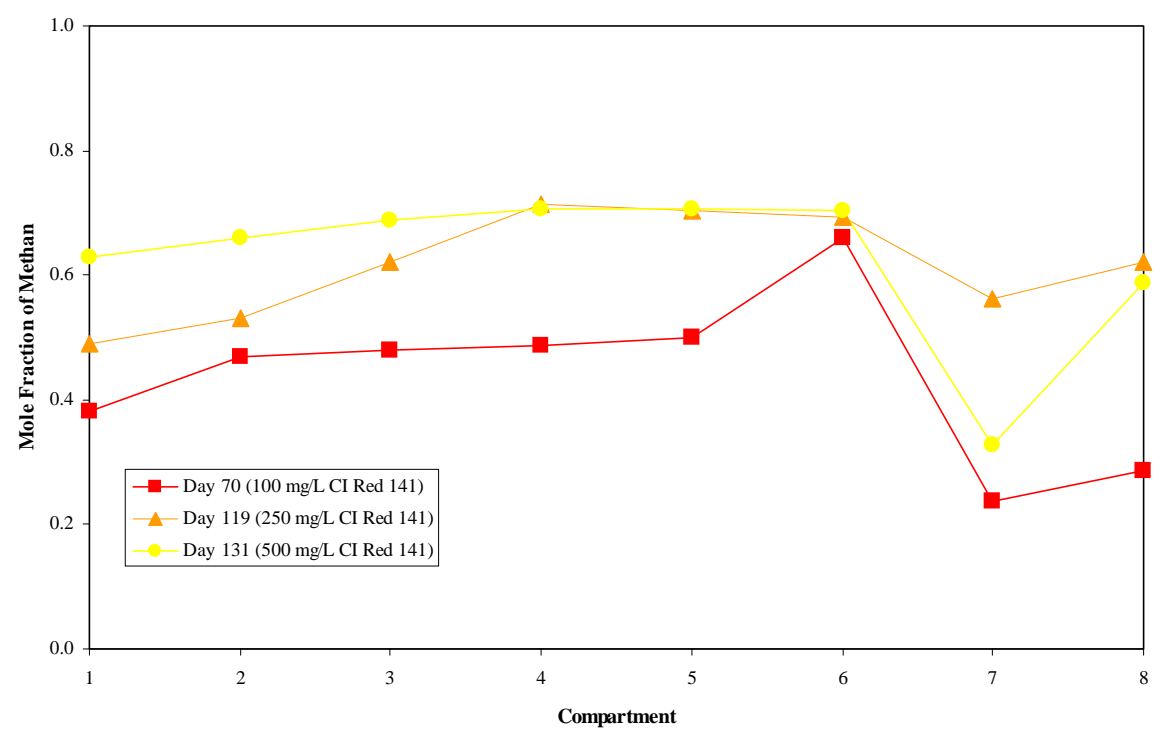

Figure 7

Results showing the methane concentration profiles through the reactor 
CARLIELL C, BARCLAY SJ and BUCKLEY CA (1996) Treatment of exhausted dyebath effluent using anaerobic digestion: Laboratory and full-scale trials. Water SA 22 (3) 225-235.

COOPER P (1995) Colour in Dyehouse Effluent. Society of Dyers and Colourists. Alden Press, London.

LAING IG (1991) The impact of effluent regulations on the dyeing industry. Rev. Prog. Coloration. 21 56-71.
SESHADRI S, BISHOP PL and AGHA AM (1994) Anaerobic/aerobic treatment of selected azo dyes in wastewater. Waste Manag. 14 (2) 127-137.

WILLETTS JRM (1999) Thermophilic Decolourisation of Textile Dye Wastewater. Ph.D. Thesis, Dept. of Civil Eng., Univ. of New South Wales, Australia. 